\title{
EXCERPTS ON NEW HUNGARIAN STATE FINANCES FROM LEGAL, ECONOMIC AND INTERNATIONAL ASPECTS**
}

Summary: $\quad$ The Hungarian national economy, struggling with public finance debts, low efficiency in budgetary policy and a weak control potential, had reached a state of crisis by the middle of the 2000s, which deepened further by the time of the 2007-2008 crisis. From 2010 onwards, as opposed to the conventional crisis management method of the International Monetary Fund (IMF) and the European Union, which was based on budgetary restrictions, adjustments were made to the budget. In 2013, the Hungarian central bank, which did not use conventional crisis management instruments either, joined in, thus becoming an institutional part of the state financial system. It was confirmed that the central bank can help fiscal consolidation and growth potential while still being able to preserve its independence. Conditions were established for the - non-conventional - rules of both fiscal and monetary interventions within the highest level national regulatory framework of the law, compliance with which is ensured by legislative and institutional guarantees.

Keywords: $\quad$ fiscal and monetary policy, crisis management, state financial consolidation, rulebased budget, European Union, IMF, Hungary

\section{INTRODUCTION: IN THE SHADOW OF SOVEREIGN DEFAULT}

The crisis that erupted in 2007-2008 seriously affected the business and public finance sectors globally, which gave rise to heightened expectations for the reconstruction of the state and rationalisation of its operation. A strong demand for helping the state appeared especially in the Eastern and Central European countries, which was partly an inheritance stemming

\footnotetext{
* $\quad$ Csaba Lentner, PhD, Full Professor, Head of Public Finance Research Institute at National University of Public Service - Public Administration Faculty, Budapest. Email address: lentner.csaba@uni-nke.hu. ORCID: https://orcid.org/0000-0003-2241-782X.

** The work was created in commission of the National University of Public Service under the priority project KÖFOP-2.1.2 VEKOP-15-2016-00001titled“PublicServiceDevelopmentEstablishingGoodGovernance”in(the)Lajos LörinczProfessor Program.
} 
from the paternalistic practice of Soviet-type economic plan periods, and partly because these countries had revitalised their economies with western capital since the end of the 1980s, but as a consequence of the crisis, western investments dried up both in terms of working capital investments and state debt financing. Hungary became one of the main "reference countries" for these disadvantageous processes, becoming practically unable to operate its public finances by the end of the 2000s. In the autumn of 2006, the government at the time announced a gigantic budget restriction program through a convergence path adjustment package to mitigate the current budget deficit, which was nearing 10 percent, and the state debt, which exceeded 80 percent of GDP ${ }^{1}$. This was aimed both at increasing the tax burdens of internal residents and at reducing the state expenditure, as well as influencing them. As a result of the austerity measures, the financial balance had improved to a certain extent, but the performance of the Hungarian economy and the aggregate financial demand had significantly fallen by the autumn of 2008, when the financial crisis also hit Europe. As a result of the inaccessibility of western financing markets and the uncertainty factors, Hungary, which financed its growth and precarious financial balance from outside, fell into a de facto sovereign default, which the International Monetary Fund, the World Bank and the European Central Bank tried to remedy with a 25 billion dollar rapid loan, thus avoiding the condition of de jure sovereign default. Until 2010, the budget policy had been characterised by the enforcement of restriction mechanisms that were expected in exchange for foreign loans. After 2010, through a budgeting practice moving towards the sharing of public burdens by increasing the taxes imposed on foreign-owned, well-capitalised enterprises and concurrently reducing the tax burdens of internal residents, they were able to drive the budget deficit to GDP ratio down to below 3 percent, and have been able to maintain this rate ever since, thus achieving fiscal ${ }^{2}$ consolidation. Increasing the solvent demand, according to the Keynesian model, and the state's active role in influencing the economy can, in terms of fiscal instruments, ensure stable state financing positions. In the period between 2006 and 2013, until consolidation began in 2013, the occurrence of sovereign default in Hungary could be described in five economic dimensions:

- the central budget is unable to function, debt service and state public services remain unsettled,

- there is a chronic social insurance deficit, especially in the pension insurance system, which results in a shortfall or significant reduction of pension payments,

- widespread bankruptcy of banks and companies, which makes the operating environment uncertain; bank deposits become inaccessible, production declines and a huge number of companies go bankrupt,

- settlement municipalities that are part of the local system of state finances declare bankruptcy all over the country, public services cease, settlements are unable to provide public utilities and public administration services, and social conflicts arise,

- as a result of large-scale insolvency of families indebted in foreign currency and masses of people experiencing more difficult living circumstances, social tranquility disintegrates.

1 Reaching 2500 billion forints, amounting to 1 billion US dollars if calculated at an exchange rate of 250 HUF to USD.

2 Hungary was relieved of the European Union's Excessive Deficit Procedure in 2013. 
Complete (de facto and de jure) sovereign default may have resulted from any of the problems becoming unmanageable in the long run. The Hungarian government had to eliminate the problems and achieve consolidation at the same time, move towards sectoral and macroeconomic stability and even make preparations for economic growth.

\section{THEORY OF FISCAL INCAPACITY}

State capacity is defined by Hanson and $\operatorname{Sigman}^{3}$ in three dimensions: 1) The state's extractive capacity, 2) The state's coercive capacity, 3) The state's administrative capacity. In other words, the state needs a revenue to maintain its operation, its internal security forces and a legal order to enforce its will (to enforce its coercive capacity), and as a third factor it must deliver public services in exchange for retained revenues. The extractive and coercive capacities ultimately help the state carry out its function (administrate capacity). Bardhan defines it as a requirement ${ }^{4}$ whereby "the state has to be strong enough to protect property rights and other institutions underpinning markets and contracts". By 2007-2008, the incapacity of enterprises operating in the administrative area of states had become so serious that it weakened state operation. As a consequence of the economic anarchy, the state's revenue sources dried up and in addition, consolidation obligations arose which caused the quality and quantity of state-provided public services to decrease. Owing to the deepening social distrust in governments, the state was only able to operate in a restricted way, which meant that the economic expansion of the neoliberal market economy that had been maintained for decades had weakened in the United States by 2007, then also in Europe by the autumn of 2008. The 2007-2008 crisis was equally caused by uncurbed market (corporate) automatisms, the difficulties of information flow between competitors (information asymmetries) and uncoordinated production. The lack of coordination in the market actors' activity dating back to the beginning of the 1970s increasingly manifested itself in commercial banking activity. The large-scale lending to secondary debtors that financial institutions predominantly focused on when granting loans generated system-level repayment problems over time with market saturation and the slowdown of the economic upheaval. These remained hidden for years, however, because of the securitisation processes ${ }^{5}$, and the lack of thorough risk assessments by credit rating agencies. While the 1929-33 crisis can be best expressed as an overproduction process in the material sphere, the root cause of the collapse which occurred in 2007-2008 can be expressed as an over-lending process. Lending processes, which were not coordinated by the state and were less and less controlled and regulated, resulted in a banking crisis, which then led to the crisis of the capital- and credit-intensive production sector, and ultimately to that of the public financing system.

3 Hanson, J. K.; Sigman, R., Leviathan's Latent Dimensions: Measuring State Capacity for Comparative Political Research. APSA 2011 Annual Meeting Paper.

4 Bardhan, P., State and Development, The Need for a Reappraisal of the Current Literature. Journal of Economic Literature Vol. 54, No. 3, 2016, pp. 862-892, p. 866.

5 Transforming irrecoverable bank receivables into securities, then buying and selling them in the capital market. See Bujtár Zs., Az árnyékbankrendszer és az értékpapirosítás az Egyesült Államokban (The shadow banking system and securitisation in the United States), Controller Info, Vol. 4, No. 3, 2016, pp. 37-41. 
In all the four institutional groups classified according to Rodrik, ${ }^{6}$ hence in the institutions ensuring the protection of property rights and the regulation of markets, and also in the ones serving stability and legitimisation, the tasks were carried out incompletely and with disruptions. As a result of market disturbances, the business value started to decrease both at the corporate and household level. The authorities expected to regulate market operation and the actors of stabilisation had already failed, so the society's dislike for government operation was growing, which meant that their confidence in the government largely weakened all over the world, and consequently the system of the neoliberal market economy did not operate smoothly. After the British mortgage markets and subsequently the economy of the United States had weakened, the spreading crisis exerted the strongest influence in the European region, in particular in the post-soviet countries and in the countries of the European Union which had a weaker position or had entered the EU later than Hungary. ${ }^{7}$

\section{CRISIS MANAGEMENT METHODOLOGY - RESTRICTION OR EXPANSION?}

While recovering from a crisis, it is justified that the economic policy aims to change the practice implemented before the crisis, and it should steer the national economy towards economic growth and financial balance. After the crisis, a period of economic reflection started all over the world, with special focus on the practical aspects of crisis management. Without claims of being exhaustive, special mention should be made of the works by Blanchard, O. and Leigh, D. (2013), Borio (2012), Koo (2014), Buti-Carnot (2012), Schick (2013), Blundell-Wignall, A., Atkinson-Hoon L. (2009), as well as Singh, Dalvinder and LaBrosse (2012). In the course of resolving the deadlock, the state took up credit and employed fiscal measures increasing the revenue side and also decreasing the expenditure side of the budget, which may be considered a common crisis management technique of the preceding decades and even of the years after the breakout of the crisis. Implementing a series of austerity measures, in return for the credit provided by the IMF and the World Bank, was a crisis management method frequently followed globally. In the case of Greece and Hungary, which had reached a critical level by 2008, it became a required crisis management method to apply restrictive measures in exchange for the international credit facilities received. Other countries in the Mediterranean region also used this kind of crisis management method, whereas in Hungary an economic policy emerged from 2010 onwards through the establishment of the new Fundamental Law and laws on public funds that basically focused on the sharing of public burdens, the termination of external indebtedness, the acquisition of state property, state regulations and the strengthening of control. Regarding international companies, telecommunication enterprises and banks, the state imposed an additional burden adjusted to their taxation power in the mostly foreign, well-capitalised sectors, whereas for internal residents it used the institution of tax reduction, mainly for income type taxes (personal income tax, corporate tax on profits). As a

6 Rodrik, D., Trade Policy Reform as Institutional Reform. In. Developing Countries and the Next Round of WTO Negotiations, Edited by Bernard Hoekman, Harvard University Handbook 2000, and Rodrik, D.; Subramanian, A., The Primacy of Institutions, Finance and Development, Vol. 40, No. 30, 2003, pp. 31-34. 
consequence of the commercial turnover expansion generated by the increase of incomes and the solvent demand, namely by the additional turnover tax revenue, and by the reduction of the mostly parallel public service capacities, the Hungarian economy was channelled towards budget consolidation.

As an essential element in the crisis management of Hungarian public funds, in the first phase priority was given to the regulations preventing indebtedness, and they were incorporated at the highest level into the new Fundamental Law of Hungary. The emerging new public funds management is rule-based, which is kept within the limits by a strong control mechanism. Managing public funds economically, creating a budgetary balance and maintaining it in the long run, and reducing state debts are such high priority economic goals in Hungary that the most fundamental principles and rules aiming at their implementation were set out in the Fundamental Law. Stable state finances provide a sound basis for creating and maintaining a firm foundation for economic growth. On the other hand, budgetary authorisation and the underlying legislative background are the results of an independent economic policy. Hungary's crisis management policy strayed from the restriction-based proposals of the IMF and the World Bank, and in many cases it was in direct contradiction with the normative rules of the European Union. The Hungarian changes were rapid, even though it is a fact that in the European region Hungary and Greece were hit most severely by the crisis that erupted in the autumn of 2008. The impacts of the Hungarian fiscal change and those of the Greek tightening policy (characteristic of the whole of the Mediterranean region) were significantly different.

- Hungary repaid the IMF loans as early as 2013-2014, while Greece has not, as of yet, been able to pay them back.

- In 2013, Hungary, after having adopted an economic policy that deviated from the EU standards, was relieved of the European Union's Excessive Deficit Procedure, whereas Greece has not yet been able to end the procedure up to this date.

- At the end of 2017, the unemployment rate in Hungary was 4 percent, while it was nearly 25 percent in Greece.

- The cumulated growth in real GDP in comparison to 2000 is 140 percent in Hungary, and 95 percent in Greece, and consequently, restricted reproduction processes have remained in place to this day.

- In Hungary, the net external debt as a percentage of GDP has decreased from 60 percent to 20 percent compared to 2010, while in Greece it has grown from 80 percent to 140 percent.

- The rate of non-performing corporate loans was 15 percent in Hungary in 2013, a number which has shrunk to 5 percent $^{8}$, while during the same period in the partner country chosen as a reference country this rate grew from 30 to 40 percent.

- Although fiscal adjustment is successful in Greece and the annual 15 percent GDP-proportionate budget deficit of 2009 had decreased to 0 percent by the end of 2016, the measures based on restrictions drove the Greek GDP down by 25 percent. $^{9}$

8 Source: Hungarian Banking Association, special data communication, 2017.

9 The shortfall from the potential level is 25 percent, while in the Mediterranean region as a whole it is 18 percent on average. 
Key macro-economic data in Hungary and Greece, 2008-2016

\begin{tabular}{|l|c|c|c|c|c|c|c|c|}
\hline & \multicolumn{2}{|c|}{$\mathbf{2 0 0 8}$} & \multicolumn{2}{c|}{$\mathbf{2 0 0 9}$} & \multicolumn{2}{c|}{$\mathbf{2 0 1 0}$} & \multicolumn{2}{c|}{$\mathbf{2 0 1 6}$} \\
\cline { 2 - 9 } & GR & HU & GR & HU & GR & HU & GR & HU \\
\hline GDP growth (\%) & -0.3 & 0.9 & -4.3 & -6.6 & -5.5 & 0.7 & -0.2 & 2.2 \\
\hline Unemployment rate (\%) & 7.8 & 7.8 & 9.6 & 10.0 & 12.7 & 11.2 & 23.5 & 5.1 \\
\hline Government debt to GDP, \% & 109.4 & 71.0 & 126.7 & 77.2 & 146.2 & 79.7 & 180.8 & 73.9 \\
\hline Government deficit to GDP, \% & -10.2 & -3.7 & -15.1 & -4.5 & -11.2 & -4.5 & 0.5 & -1.9 \\
\hline Inflation rate (\%) & 4.2 & 6.1 & 1.2 & 4.2 & 4.7 & 4.9 & -0.8 & 0.4 \\
\hline
\end{tabular}

Source: Eurostat, Worldbank

\section{LEGAL BACKGROUND TO THE CONSOLIDATION OF PUBLIC FINANCES IN HUNGARY}

Hungarian crisis management is based on political and social authorisation ${ }^{10}$ and on the legislative regulation based on it, which was elevated to the constitutional legislative level in 2011. In the Fundamental Law of Hungary, ${ }^{11}$ the articles on public funds and local governments set out as a cardinal provision that the Parliament may not adopt an act on the central budget as a result of which the state debt would exceed half of Gross Domestic Product. Being aware of the actual data and the overspending practice in the period before 2010, the provision says that as long as the state debt exceeds half of Gross Domestic Product, the Parliament may only adopt an act on the central budget that provides for state debt reduction in proportion to GDP. Any derogation from these rules may only be allowed accompanied by a special legal order and to the extent necessary to mitigate the consequences of the circumstances triggering the special legal order, or, in case of an enduring and significant national economic recession, to the extent necessary to restore the balance of the national economy.

It is an essential element that the government is obliged to implement the central budget in a lawful and reasonable manner, managing public funds effectively while ensuring transparency, during which, with the exceptions defined in the case of a special legal order, it is not allowed to take a loan nor undertake a financial commitment that would result in state debt exceeding half of GDP. It is a transitional rule that as long as the state debt exceeds half of Gross Domestic Product, with the exceptions defined in the case of a special legal order, no such borrowing may be contracted and no such financial commitment may be undertaken in the course of the implementation of the central budget that would result in an increase, as compared to the previous year, of the ratio of state debt in relation to GDP. As long as state debt exceeds half of GDP, rules restricting any investigation by the constitutional court are enforced. Such special rules apply to the acts on the central budget, the implementation of the central budget, central taxes, duties and contributions, customs duties and the central conditions for

10 In 2010, the winning political forces in the parliamentary elections obtained a two-third majority and they have been able to maintain this balance of power continuously. Thus it has become a smooth process in Parliament to adopt and implement the laws intended to reduce state debt, which was made a central issue of Hungarian state operation. 
local taxes. The Constitutional Court may only review such acts pertaining to public finances in connection with the rights to life and human dignity, to the protection of personal data, to freedom of thoughts, conscience and religion, or to the rights regarding Hungarian citizenship and it may only annul these acts for the violation of these rights. The Constitutional Court is entitled to annul the acts on the above subject-matters without limitation if the procedural requirements for the creation and promulgation of the acts have not been met according to the provisions laid down in the Fundamental Law of Hungary.

The subsystem of local governments is considered as part of the public finances, and this subsystem is regulated so that in order to keep the state budget balance, the borrowing of the local government, the rate of which is specified in legislation, or other commitments undertaken by the local government may be subject to conditions or the government's consent. Zéman emphasises that the enterprises operated by local governments are also determining parts of the local government sector, therefore their balanced operation is important for ensuring high standards for the population. To this end, it is indispensable to have a stable source structure and control. ${ }^{12}$

The chapter of the Fundamental Law on public funds and the acts relating to public funds, in particular the cardinal acts, make up a closed unit. They ensure Hungary's financial stability and behind this also the responsible management ${ }^{13}$ of public funds and public assets. Parliament created the Stability Act $^{14}$ for the implementation of the Fundamental Law in order to ensure the country's financial stability and budgetary sustainability, facilitate the independent study of the justification of the Act on the Central Budget and the reduction of state debts. This cardinal law includes rules on the calculation of state debt and rules restricting its growth. Furthermore, it details the basic rules of operation of the sharing of public burdens, the pension system and the Fiscal Council. The Fiscal Council, acting as a body, participates in drafting the Act on the Central Budget and in the control of the provisions pertaining to the extent of state debt. During the performance of its activity the Council is only subject to the Fundamental Law and the acts. The Council members form their opinions independently and are also independent of one another in the representation of their standpoints. ${ }^{15}$

The balance of public finances and the guarantees of a transparent, efficient and controllable management of public funds are governed by Act CXCV of 2011. Preserving local government traditions and enforcing the basic principles defined in the European Charter of Local Self-Government, Act CLXXXIX of 2011 on the local governments of Hungary guarantees the right of local voters to self-government, the contribution of local governments to the imple-

12 Hegedús, Sz.; Zéman, Z., Tökeszerkezeti elméletek érvényesülésének vizsgálata a hazai önkormányzati tulajdonú gazdasági társaságok körében (Study of the Enforcement of Theories on Capital Structure among Hungarian Businesses in Local Government Ownership), Statisztikai Szemle, Vol. 94, No. 10, 2016, pp. 1032-1049., and: Zéman Z.; Tóth A., Az önkormányzatok és közüzemi vállalatok teljesítményértékelése (Performance evaluation of local governments and public utility companies), Adózási pénzügytan és államháztartási gazdálkodás (Taxation Financing and Public Finance Management). Lentner Cs., ed., Nemzeti Közszolgálati Egyetem (National Public Service University), Budapest, 2015, pp. 829-853.

13 An interesting aspect is the management of state-owned enterprises which may be also subject to European corporate governance provisions. For further details see: Kecskés A., A felelős társaságirányítás európai rendszere (The European System of Corporate Governance) Európai Jog (European Law) Vol. 16, No. 3. 2016, pp. 28-38. Act CXCIV of 2011, Hungarian Gazette, 2011/164.

15 Regarding the operation of the Fiscal Council see: Kovács Á., A Költségvetési Tanács a Magyar Alaptörvényben - Vázlat az intézményfejlődésről és az európai uniós gyakorlatról (Kovács Á, The Fiscal Council in the Fundamental Law - Sketch on Institutional Development and European Union Practice), Pénzügyi Szemle (Financial Review), Vol. 61, No. 3, 2016, pp. 320-337. 
mentation of state goals and at the same time also the strengthening of local communities' self-support ability and the creation of the conditions required for local self-government.

The Hungarian Parliament, exercising its budgetary right, ${ }^{16}$ annually approves a budget plan proposed by the government and entitled Act on Hungary's Central Budget. At the end of the fiscal year, the government compiles the Draft Act on Final Accounts, which is reviewed by the State Audit Office, then the Parliament discusses it and creates the Act on Final Accounts.

The basic rules pertaining to national assets are included in the Fundamental Law and in the act adopted for its implementation, Act CXCVI of 2011 on National Assets. ${ }^{17}$ The revenues of public finances provide the funds that may be used for expenditures related to the performance of state tasks and their financing. The implementation of public duties requires not only funding, but also other asset elements, such as, in particular buildings, structures, vehicles, machines, equipment, intellectual products, property rights and reserves. Management with a budgetary-financial approach, which builds on revenues and expenditures, is strongly linked to asset management with an inventory approach, since the use of and return on assets also satisfies public needs. The Fundamental Law provides that "the property of the State and local governments shall constitute national assets. The management and protection of national assets shall aim at serving public interest, meeting common needs and preserving natural resources, as well as at taking into account the needs of future generations." The Fundamental Law provides enhanced protection for public funds and national assets, and lays down guarantees for their responsible and transparent management.

The fundamental function of national assets is to ensure the performance of public tasks. The Act on National Assets also defines the concept of the public task. A public task is a state or a local government task defined in law, which is performed by the obliged party for public interest in compliance with the requirements and conditions defined in law, including the provision of public services for the population, tasks of public interest arising from the state's obligations undertaken in international agreements, and the provision of the infrastructure needed for the completion of such tasks. The national assets shall be managed in a responsible manner for their intended purpose.

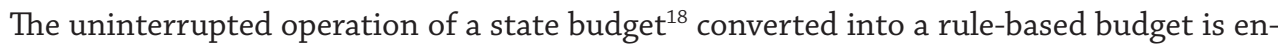
sured by additional laws. The purpose of the Act on the Rules of Taxation is to provide a uniform regulation for the rights and obligations of tax payers and the tax authorities in order to ensure the legality and the effectiveness of the procedure. The tax payers and the tax authorities may exercise their rights and fulfil their obligations according to the Act on the Rules of Taxation. It is through this mechanism that the acts on taxes are observed and the subsidies are disbursed. So the procedure of the revenues flowing into and the expenditure flowing out of public finances is governed by the Act on the Rules of Taxation. The acts on taxes (personal income tax, value added tax, corporate profit tax, etc.) set out detailed rules for the individual types of taxes. The operative fiscal processes, as mentioned before, are managed by the National Tax and Customs Administration.

16 Kecskés A., Inside and Outside the Province of Jurisprudence, Rechtstheorie, Vol. 46, No. 4, 2015, pp. 465-479.

17 Kecskés A., A szuverén alapok jogi háttere és nemzetgazdasági szerepvállalása (Legal Background and National Economic Role of Sovereign Funds), Pro Futuro, Vol. 6, No. 2, 2016, pp 151-169, p. 166.

18 Kovács Á., Rule-Based Budgeting: The Road to Budget Stability. The Hungarian Solution, Polgári Szemle (Civic Review), Vol. 13, Special Issue, 2017, pp. 39-63. 
The control over state assets and public funds, deriving from the Fundamental Law, appears in the Act on the State Audit Office. ${ }^{19}$ Chapter VIII of the Public Finances Act distinguishes three levels of state control: control by the State Audit Office, control by the government and the internal control of public finances. Funds are supplied to entities operating under the budgetary order and the public funds are managed through the State Treasury, whereas state debts are managed through the State Debt Management Centre belonging to the organisational structure of the Hungarian State Treasury.

\section{LEGAL REGULATION AND PRACTICE OF CENTRAL BANKING ACTIVITY}

Article 41 of the Fundamental Act, included in the chapter on public funds, stipulates that the National Bank of Hungary is the central bank of Hungary responsible for monetary policy in the manner specified in a separate cardinal act (the Central Bank Act of 2011 and then of 2013). The primary objective of the National Bank of Hungary is to achieve and maintain price stability. Furthermore, without prejudice to its primary objective, it supports the economic policy of the government, using the monetary policy instruments at its disposal; it is declared that the central bank is an institutional part of the system of public finances, and with this, the responsibility for the entire national economy was codified in the Fundamental Law. ${ }^{20}$

The National Bank of Hungary is a member of the European System of Central Banks (ESCB). The National Bank of Hungary and the members of its decision-making bodies are independent in carrying out the tasks and meeting the obligations conferred upon them by law, and may not seek or take instructions from the government, the institutions and bodies of the European Union, the governments of its Member States and any other bodies, other than the European Central Bank. ${ }^{21}$ The government and all other organisations respect this principle and do not seek to influence the members of the decision-making bodies of the National Bank of Hungary in the performance of their tasks. The Governor of the National Bank of Hungary is required to report to Parliament in writing and orally.

The Governor of the National Bank of Hungary reports to Parliament on the activities and monetary policy of the National Bank of Hungary on an annual basis. He makes a written report to the Parliamentary Standing Committee in charge of economic affairs on a six-monthly basis on the activities of the National Bank of Hungary in the past six months, with content corresponding to his annual report. The National Bank of Hungary must be consulted regarding the drafts of decisions and legislative provisions related to the tasks of the National Bank

19 Act LXVI of 2011 Hungarian Gazette 2011/51. For a more detailed overview of the regulatory framework of the State Audit Office, see Domokos L., Az Állami Számvevőszék jogosítványainak kiteljesedése az új közpénzügyi szabályozás tükrében (Extension of the powers of the State Audit Office with regard to the new public funds regulations), Pénzügyi Szemle (Public Finance Quarterly), Vol. 62, No. 2, 2016, pp. 299-319. growth, and achieve a positive change in competitiveness with the help of the monetary policy tools of the National Bank of Hungary.

21 Kecskés A., Kihivások az árnyékbankrendszer jogi szabályozásában (Challenges in the legal regulation of shadow banking system) Miskolci Jogi Szemle (Miskolc Law Review), Vol. 11, No. 2, 2016, pp. 42-54, p. 51. 
of Hungary and the operation of the financial system. When the government has approved the budget, the Minister for the National Economy informs the National Bank of Hungary of the draft bill for the central budget without delay. The National Bank of Hungary is entitled to send their opinion on the draft directly to the Minister. This opinion is presented at the Budget Committee meeting by the Governor of the National Bank of Hungary. However, the presented opinion does not restrict the Governor of the National Bank of Hungary from freely exercising his rights as a member of the Budget Committee.

In 2013, central banking mechanisms took a new course in Hungary: this is manifest in the reduction of the base rate, the refashioning of the monetary policy instruments, the narrowing of the interest rate corridor, the Funding for Growth Scheme, ${ }^{22}$ and the Self-Financing Programme to help public finance management. ${ }^{23}$

After 2013, the central bank's new course achieved its goal in the refinancing efforts: it provided small and medium-size enterprises as well as agricultural producers with access to the resources required for their development, and this was expressly aimed at supporting the government's fiscal policy, as it resulted in economic growth, an increase in domestic solvent demand and in new value. In terms of the cumbersome management of public debt, the actions taken to promote domestic financing through lower rates also benefited the country's financial stability. Through these refinancing actions, the central bank, which obviously does not generate public funds (it is not subject to the Act on Public Finances, it does not collect taxes, and it does not grant aid constituting public funds), nevertheless became part of the system of Hungarian public finances. Thus, after more than a decade of intermission, the real sector of the economy, which had been eliminated by 1995, and the (partial) refinancing of public debt, which had been terminated by 2000 in the course of the lead-up to the accession to the European Union, were essentially restored in $2013 .{ }^{24}$

\section{OUTCOMES OF COORDINATION IN HUNGARIAN PUBLIC FINANCES}

With the legislative regulation of the coordination of fiscal and monetary mechanisms, and with the help of practical mechanisms implemented in this spirit, Hungary successfully stabilised the public finance sector and triggered growth. The crisis management carried out by the increasingly active central bank played a pivotal role in this process. ${ }^{25}$

22 HUF 3500 billion was allocated to this scheme, essentially for long-term investment loans at low (refinancing) rates, similar to the Funding for Lending scheme of the Bank of England and the Quantitative Easing programme run by FED.

23 In the framework of the central bank's Self-Financing Programme, by "channelling" domestic commercial banks towards the market of government securities, the central bank increased the domestic ratio within public debt, and thus cut the country's external exposure. world (FED, BoE and then the ECB). 
When Hungary was hit by the 2008 crisis, ${ }^{26}$ it was vulnerable and defenceless. One reason for this, among others, was that the Constitution in force before 2011 did not contain any chapter on public finances; in other words, there was no constitutional rule, nor a guarantee enforcing compliance, for the limitation of excessive sovereign indebtedness. Public finance control was inefficient, and the central bank's policy only focused on anti-inflationary objectives. ${ }^{27}$ A comparison of operation before and after 2013 confirms the beneficial impacts of proactive central banking on fiscal positions.

Every year between 2002 and 2006, Hungary's budget balance showed a deficit amounting to 6-8 percent of gross domestic product (GDP), and even in 2007 the deficit well exceeded 4 percent. The reorganisation of public finances started in 2011, when the balance calculated according to the then valid methodology of the European Union (EA95) suddenly fell to 4 percent of GDP (primarily due to the single budget revenues from the transformation of the pension fund scheme). Since 2012, the budget deficit has remained below 3 percent of GDP according to every EU-compatible indicator. The deficit decrease was due, in part, to the improvement of the primary balance (net of the interest balance), and to falling net interest costs after 2013.

The National Bank of Hungary's refashioned monetary policy ${ }^{28}$ contributed considerably to the reduction of the interest costs of the budget through cutting government security yields. ${ }^{29}$ According to the National Bank of Hungary's estimate, between 2013 and 2015, the interest reduction impact represented about 1 percent of GDP, and this was due, among other things, to the easing cycles, to the central bank's focused programmes, in particular, the Self-Financing Programme, ${ }^{30}$ and to the consistent and appropriate communication of the essence of the monetary policy. ${ }^{31}$ Due to a gradual repricing of the sovereign debt, interest costs are expected to continue falling in the future, and the annual saving on interest may amount to as much as 1.7 percent of GDP, which translates to HUF 600-700 billion. In addition, reduction in the central bank's interest costs should also be taken into consideration, as since

26 For more on this on this topic and on successful crisis management, see: Matolcsy, Gy.: Egyensúly és növekedés (Balance and Growth), Kairosz, Budapest, 2015.

27 The State Audit Office did not have sufficient powers to control public utility service provider companies in municipal ownership. Thus, due to legal disorganization, the findings of SAO investigations remained without any consequences.

28 Lehmann, K.; Palotai D. and Virág B., eds., A magyar út -célzott jegybanki politika (The Hungarian Way - Targeted Central Banking Policy). National Bank of Hungary, Budapest, 2017. Let us add that change in monetary policies is a general trend throughout the world. About the same on a theoretical level: Tatay T., A központi banki feladatok változása (Changes in Central Banking Duties). In: Kálmán J. (ed.), Állam - válság - pénzügyek: A pénzügyi piac szabályozásának és felügyeletének aktuális kérdései (State Crisis - Finances: Current Issues in the Regulation and Supervision of the Financial Market), Batthyány Lajos Szakkollégium, Győr 2015.pp. 53-76, and Tatay T., A központi bankok változó szerepe (The Changing Role of Central Banks), Polgári Szemle, Vol. 11, No. 1-3, 2015, pp. 90-102.

29 The macro-economic data included in Chapter VI are presented on the basis of the special data issues and official statistics of the National Bank of Hungary.

30 Kolozsi P. P. and Hoffmann M.: A külsô sérülékenység csökkentése monetáris politikai eszközökkel - A Magyar Nemzeti Bank jegybanki eszköztárának megújítása (2014-2016) (Reducing External Vulnerability by Monetary Policy Means - Renewal of the Hungarian National Bank's Central Banking Instruments), Pénzügyi Szemle Vol. 61, No. 1, 2016a, pp. 9-34; Kolozsi P. P. and Hoffmann M. (eds.) Az Önfinanszírozási program első két éve (The First Two Years of the Self-Financing Programme), 2016b; Kolozsi P. P.: Stabilabb és olcsóbb finanszírozást hozhatnak az MNB új eszközei (The New Instruments Used by the National Bank of Hungary May Result in More Stable and Cheaper Financing), 2014. URL= https://www.mnb.hu/letoltes/kolozsi-pal-peter-jegybanki-eszkozok. pdf. Accessed on 09 November 2017.

31 National Bank of Hungary: Félidős jelentés 2013-2016, (Interim report, 2013-2016) 2016. URL= https://www.mnb.hu/letoltes/ felidos-jelentes-2013-2016-hun-0303.pdf. Accessed 09 November 2017. 
the start of quantitative easing, the National Bank of Hungary's cumulative interest savings have reached nearly 2 percent of GDP (representing an additional amount of more than HUF 600 billion). ${ }^{32}$ Moreover, interest cuts boosted domestic investments and consumption, while the Funding for Growth Programme launched in 2013 provided direct assistance to financing small and medium-sized businesses.

Hungary's sovereign debt amounted to 55 percent of GDP in 2002, this ratio rose to 65 percent in 2007, and to 80 percent in 2010. It is important to see that while in 2004 slightly more than 25 percent of the sovereign debt was denominated in foreign currency, in 2008 this ratio was already 40 percent, and by 2010 it rose above 50 percent. The year of the adoption of the Fundamental Law was thus a milestone in this respect, too. Up to 2011, government debt continued to increase significantly, and then debt started to fall: moving from the 80 percent ratio by 2016 it fell just below 75 percent of GDP, and this can be considered a major achievement due to the "inertia" of debt. Meanwhile, the ratio of Foreign exchange (FX) debt to the total sovereign debt dropped from above 50 percent to around 20-25 percent, which means that indebtedness in FX was practically halved, and exposure in FX as well as the external vulnerability of the entire Hungarian economy was considerably reduced (these steps were achieved through the charge-off of household FX loans). ${ }^{33}$

In 2010, the monthly inflation rate was around 4-5 percent. Following the year of the adoption of the Fundamental Law (2011), due in large part to international developments and to utility cost cuts, the inflation rate, after an initial slight rise, fell considerably and finally practically tapered off. This enabled the National Bank of Hungary to launch its above-mentioned easing cycle as early as mid-2012, which resulted, later on, in a changed global economic environment, and in the successful avoidance of deflation. ${ }^{34}$

Prior to the adoption of the Fundamental Law, Hungary's growth data remained moderate: while between 2002 and 2005, Hungary's GDP increased faster than the average of the Visegrád Group ${ }^{35}$ (4 percent to 2-3 percent of the regional average), between 2006 and 2010, it typically remained below the value of the regional competitors. As a combined effect of fiscal stabilization and the breakthrough in monetary policy, Hungary started to re-establish itself in 2013: the growth rate has been significantly exceeding the average of the Euro Area, steadily remaining in the 2-4 percent range. According to the forecasts of the April 2017 Convergence Programme, the pace of economic growth is set at 4 percent in Hungary between 2017 and 2021, which represents a substantive rise even in a medium-term comparison. ${ }^{36}$ The central bank's Funding for Growth Programme and base rate cuts boosted economic growth. The rate of economic growth would have been 1.2, 2.6, 2.2 and 1.7 percent without intervention and it was 2.1, 4, 3.1 and 2.2 percent as a result of the central bank's intervention in 2013, 2014,

32 Felcser D.; Soós G. D.; Váradi B., A kamatcsökkentési ciklus hatása a magyar makrogazdaságra és a pénzügyi piacokra (Impact of Easing on Hungarian Macro-economy and on the Financial Markets), Hitelintézeti Szemle, Vol. 14, No. 3, 2015, pp. 39-59.

Lentner Cs.: Taxonomic Overview of the Evolution and Consolidation of Household Lending, Vol. 60. No. 3, 2015, pp. 305-318.

Without cutting the central bank base rate, the inflation rate would have dropped to -1.7 percent, representing deflation; the actual figure was, however, -0.1 percent. By 2016, a deflation rate of -1.5 percent could have been achieved, while in reality a 0.4 percent inflation was recorded.

Czech Republic, Hungary, Poland, Slovakia.

Government of Hungary: The Convergence Programme of Hungary, 2017-2021, 2017 URL= https://ec.europa.eu/info/sites/ info/files/2017-european-semester-convergence-programme-hungary-hu-2.pdf. Accessed on 09 November 2017. 
2015 and 2016, respectively. The growth rates generated by the central bank also indirectly improved the tax and duty revenues of the government budget, and consequently, the general government balance, by approximately 0.3-0.4 percent per annum.

As a result of the low and moderated inflationary environment created by the central bank, the longer-term investment loans bearing lower than market rates, the cheaper government debt financing due to the low interest rate trajectory, and lending to businesses and households at lower rates benefit the complex objectives of the national economy and the society. Leaving the pre-2013 single purpose - single instrument (exclusively anti-inflationary) policy behind, the central bank has again become a propelling force in public finances, in the corporate environment, and in household economy. The assignment of several mandates to the central bank not only makes the central bank a supporter of the financial policy of the fiscal administration, and involves it in economic policy as a proactive contributor, but also enables it to serve the public good in the broad sense of the term. Capitalising on its multiple mandates, the National Bank of Hungary also adjusts to the international trend, as now it has functions similar to the US and British central banks and to the European Central Bank, which has recently become more active in boosting business and in the market of government securities.

\section{CONCLUSION}

Fiscal adjustments can also be made and economic growth revamped by methods other than those used in the decade-long (conventional) practice (IMF, EU).

The monetary policy practice relying on multiple mandates and multiple instruments, developed by the National Bank of Hungary during the crisis to replace the single goal - single instrument (exclusively anti-inflationary) policy, favoured in the European continental area in the early phase of the European Union integration, can serve as a model.

Crisis management, whether fiscal or using monetary policy means, brought success in Hungary because of the codification of a powerful statutory regulation (at the highest level); in other words, budget management was placed on a regulatory footing, and now legal and institutional guarantees ensure budget discipline. This restored the government's ability to have control.

As a prerequisite of successful crisis management, fiscal and monetary mechanisms must be coordinated in a way not to jeopardize the central bank's independence, although the monetary instruments used for crisis management (Funding for Growth and similar schemes) cannot last forever. With the crisis subsiding, market conditions must take over the crisis managing role of fiscal and monetary policy in the national economy; in other words, subsidies, the government's interventions in the economy and the central bank's crisis management schemes must be replaced by market boosting impetuses.

An ideal public finance system fundamentally responds to the challenges of the national economy, but it cannot remain averse to new international trends either, and cannot rely exclusively on the given country's economic history and experience. Public finance management is based on the proportionate combination of these, properly dimensioned in time and space. 


\section{REFERENCES}

1. Bardhan, P., State and Development, The Need for a Reappraisal of the Current Literature. Journal of Economic Literature Vol. 54, No. 3, 2016, pp. 862-892.

2. Blanchard, O.; Leigh, D. (2013): Growth Forecast Errors and Fiscal Multipliers, IMF Working Papers, No. 13/1.

3. Blundell-Wignall, Adrian, Paul Atkinson and Se Hoon Lee (2009), "Dealing With the Crisis and Thinking about the Exit Strategy”, OECD Journal: Financial Market Trends, Vol. 2009/1.

4. Borio, C. (2012): The Financial Cycle and Macroeconomics: What Have we Learnt?, BIS Working Papers, No. 395, www.bis.org/publ/work395.htm.

5. Bujtár, Zs., Az árnyékbankrendszer és az értékpapírosítás az Egyesült Államokban (Shadow Banking System and Securitisation in the United States), Controller Info, Vol. 4, No. 3, 2016, pp. 37-41.

6. Domokos, L., Az Állami Számvevôszék jogosítványainak kiteljesedése az új közpénzügyi szabályozás tükrében (Extesion of the Powers of the State Audit Office with Regard to the New Public Funds Regulations), Pénzügyi Szemle, Vol. 62, No. 2, 2016, pp. 299-319.

7. Felcser, D.; Soós G. D.; Váradi B., A kamatcsökkentési ciklus hatása a magyar makrogazdaságra és a pénzügyi piacokra (Impact of Easing on Hungarian Macro-Economy and on the Financial Markets), Hitelintézeti Szemle, Vol. 14, No. 3, 2015, pp. 39-59.

8. Hanson, J. K.: Sigman, R., Leviathan's Latent Dimensions: Measuring State Capacity for Comparative Political Research. APSA 2011 Annual Meeting Paper.

9. Hegedűs, Sz., Zéman, Z.: Tőkeszerkezeti elméletek érvényesülésének vizsgálata a hazai önkormányzati tulajdonú gazdasági társaságok körében (Study of the Enforcement of Theories on Capital Structure among Hungarian Businesses in Local Government Ownership), Statisztikai Szemle, Vol. 94, No. 10, 2016, pp. 1032-1049.

10. Kecskés A.: A szuverén alapok jogi háttere és nemzetgazdasági szerepvállalása (Legal Background and National Economic Role of Sovereign Funds), Pro Futuro, Vol. 6, No. 2, 2016, pp. 151-169.

11. Kecskés A.: A felelós társaságirányitás európai rendszere (The European System of Corporate Governance) Európai Jog (European Law) Vol. 16, No. 3., 2016, pp. 28-38.

12. Kecskés A.: Inside and Outside the Province of Jurisprudence, Rechtstheorie, Vol. 46, No. 4, 2015, pp. 465-479.

13. Kecskés A.: Kihivások az árnyékbankrendszer jogi szabályozásában (Challenges in the Legal Regulation of Shadow Banking System) Miskolci Jogi Szemle (Miskolc Law Review), Vol. 11, No. 2, 2016, pp. 42-54.

14. Kolozsi P. P. and Hoffmann M.: A külső sérülékenység csökkentése monetáris politikai eszközökkel - A Magyar Nemzeti Bank jegybanki eszköztárának megújítása (2014-2016) (Reducing External Vulnerability by Monetary Policy Means - Renewal of the Hungarian National Bank's Central Banking Instruments), Pénzügyi Szemle, Vol. 61, No. 1, 2016, pp. 9-34.

15. Kolozsi P. P. and Hoffmann M. (eds.): Az Önfinanszírozási program első két éve (The First Two Years of the Self-Financing Programme), 2016b, National Bank of Hungary, Budapest.

16. Koo, R. (2014): Balance Sheet Recession is the Reason for Secular Stagnation, in Secular Stagnation: Facts, Causes and Cures. VOXEU.org e-book.

17. Kovács Á., A Költségvetési Tanács a Magyar Alaptörvényben - Vázlat az intézményfejlödésröl és az európai uniós gyakorlatról (The Fiscal Council in the Fundamental Law - Sketch on Institutional Development and European Union Practice), Pénzügyi Szemle, Vol. 61, No. 3, 2016, pp. 320-337. 
18. Kovács Á.: Rule-Based Budgeting: The Road to Budget Stability. The Hungarian Solution, Polgári Szemle, Vol. 13, Special Issue, 2017, pp. 39-63.

19. Lehmann K.; Palotai D. and Virág B., (eds.): A magyar út -célzott jegybanki politika (The Hungarian Way - Targeted Central Banking Policy). National Bank of Hungary, Budapest, 2017.

20. Lentner, Cs.: A lakossági devizahitelezés kialakulásánakés konszolidációjának rendszertani vázlata (Taxonomic Overview of the Evolution and Consolidation of Household Lending), Pénzügyi Szemle, Vol. 60. No. 3, 2015, pp. 305-318.

21. Matolcsy, Gy.: Egyensúly és növekedés (Balance and Growth). Kairosz Kiadó, Budapest, 2015.

22. Muti, M.; Carnot, N.: The EMU Debt Crisis: Early Lessons and Reforms. JCMS 2012 Vol. 50. No 6. pp. 899-911; DOI: 10.1111/j.1468-5965.2012.02288.

23. Rodrik, D.: Trade Policy Reform as Institutional Reform. In: Developing Countries and the Next Round of WTO Negotiations, Hoekman, B. (ed., Harward University Handbook 2000.

24. Rodrik, D. and Subramanian, A.: The Primacy of Institutions, Finance and Development, Vol. 40, No. 30, 2003, pp. 31-34.

25. Schick, A.: Lessons from the crisis, OECD Journal on Budgeting, Vol. 12, No 3, http://dx.doi. org/10.1787/budget-12-5k47tb29wn6h.

26. Singh, D. and John Raymond LaBrosse, J. R.: Developing a Framework for Effective Financial Crisis Management, OECD Journal: Financial Market Trends, Vol. 2011/2. http://dx.doi.org/10.1787/ fmt-2011-5k9cswn0h042.

27. Tatay, T.: A központi banki feladatok változása (Change in Central Banking Duties). In: Kálmán J. (ed.): Állam - válság - pénzügyek: A pénzügyi piac szabályozásának és felügyeletének aktuális kérdései (State, crisis and finances: current issued in the regulation and supervision of the financial markets), Batthyány Lajos Szakkollégium, Győr 2015, pp. 53-76.

28. Tatay T., A központi bankok változó szerepe (The Changing Role of Central Banks), Polgári Szemle, Vol. 11, No. 1-3, 2015, pp. 90-102.

29. Zéman Z.; Tóth A., Az önkormányzatok és közüzemi vállalatok teljesitményértékelése (Assessment of the performance of local governments and public utility companies) In: Lentner, Cs. (ed.): Adózási pénzügytan és államháztartási gazdálkodás. (Fiscal finances and public finance management), Nemzeti Közszolgálati Egyetem, Budapest, 2015, pp. 829-853.

\section{LIST OF REGULATIONS, ACTS AND COURT DECISIONS}

1. Act CXCIV of 2011, Hungarian Gazette, 2011/164.

2. Act LXVI of 2011, Hungarian Gazette, 2011/51.

3. Art. 36 of the Fundamental Law of Hungary, Hungarian Gazette, 2011/43, 2013/55, 2013/163, 2016/96.

\section{WEBSITE REFERENCES}

1. Kolozsi P. P.; Stabilabb és olcsóbb finanszírozást hozhatnak az MNB új eszközei eszközei (The New National Bank of Hungary Instruments May Result in More Stable and Cheaper Financing), 2014. URL= https:// www.mnb.hu/letoltes/kolozsi-pal-peter-jegybanki-eszkozok.pdf . Accessed 09 November 2017. 
2. Magyar Nemzeti Bank: Félidős jelentés 2013-2016 (Interim Report 2013-2016), 2016. URL = https:// www.mnb.hu/letoltes/felidos-jelentes-2013-2016-hun-0303.pdf. Accessed 09 November 2017.

3. Magyarország Kormánya: Magyarország Konvergencia Programja 2017-2021, (Government of Hungary: The Convergence Programme of Hungary) 2017. URL = https://ec.europa.eu/info/sites/ info/files/2017-european-semester-convergence-prog ram me-hungary-hu-2.pdf Accessed 09 November 2017. 


\section{IZVACI O NOVIM MAĐARSKIM DRŽAVNIM FINANCIJAMA S PRAVNOG, EKONOMSKOG I MEĐUNARODNOG STAJALIŠTA**}

\section{Sažetak}

Mađarsko nacionalno gospodarstvo, koje je rješavalo dugove javnih financija, slabu učinkovitost u proračunskoj politici i slab kontrolni potencijal, sredinom 2000-ih zahvatila je kriza koja se dodatno produbila 2007. i 2008. godine. Prilagodba proračuna provodi se od 2010. godine, unatoč uobičajenoj metodi upravljanja kriznim situacijama Međunarodnog monetarnog fonda (MMF) i Europske unije, koja se temeljila na proračunskim ograničenjima. Godine 2013. Mađarska središnja banka koja nije koristila konvencionalne instrumente upravljanja krizom, postala je institucionalni dio državnog financijskog sustava. Potvrdilo se da središnja banka može pomoći fiskalnoj konsolidaciji i potencijalu rasta, i unatoč tome zadržati svoju neovisnost. Uspostavljeni su uvjeti - nekonvencionalnih - pravila za fiskalne i monetarne intervencije unutar najvišeg nacionalnog regulatornog zakonskog okvira čija se usklađenost osigurava zakonodavnim i institucionalnim jamstvima.

Ključne riječi: $\quad$ fiskalna i monetarna politika, upravljanje krizama, konsolidacija državnih financija, proračun utemeljen na pravilima, Europska unija, MMF, Mađarska

This work is licensed under a Creative Commons

Attribution-NonCommercial 4.0 International License.

* $\quad$ Dr. sc. Csaba Lentner, redoviti profesor, Predsjednik Instituta za istraživanje javnih financija pri Nacionalnom sveučilištu za javne službe, Fakultet javne uprave, Budimpešta, 2 Ludovika tér, Republika Mađarska. Adresa e-pošte: lentner.csaba@uninke.hu. ORCID: http://orcid.org/0000-0003-2241-782X.

** Rad je nastao prema nalogu National University of Public Servicea u okviru projekta KOPP-2.1.2-VEKOP-15-2016-00001 pod nazivom "Razvoj javnih službi radi uspostavljanja dobrog upravljanja" u programu profesora Lajosa Lőrincza. 